\title{
PENGARUH PENGEROLAN PANAS TERHADAP KARAKTER PADUAN Zr-0,6Nb-0,5Fe-0,5Cr
}

\author{
Sungkono, Siti Aidah \\ Pusat Teknologi Bahan Bakar Nuklir- BATAN \\ Kawasan Puspiptek, Serpong, Tangerang Selatan, 15314 \\ e-mail: sungkhana@gmail.com
}

(Naskah diterima : 14-08-2015, Naskah direvisi: 10-09-2015, Naskah disetujui: 18-09-2015)

\begin{abstract}
ABSTRAK
PENGARUH PENGEROLAN PANAS TERHADAP KARAKTER PADUAN Zr-0,6Nb-0,5Fe0,5Cr. Paduan $\mathrm{Zr}-0,6 \mathrm{Nb}-0,5 \mathrm{Fe}-0,5 \mathrm{Cr}$ hasil pengerolan panas telah diteliti karakternya. Tujuan penelitian ini adalah mendapatkan data pengaruh pengerolan panas terhadap karakteristik mikrostruktur, kekerasan dan fasa yang terbentuk dalam paduan $\mathrm{Zr}-0,6 \mathrm{Nb}-0,5 \mathrm{Fe}-0,5 \mathrm{Cr}$. Proses pengerolan panas paduan $\mathrm{Zr}-0,6 \mathrm{Nb}-0,5 \mathrm{Fe}-0,5 \mathrm{Cr}$ dilakukan pada temperatur $800{ }^{\circ} \mathrm{C}$ dengan waktu penahanan (soaking time) 1,5 dan 2 jam dan reduksi ketebalan 5-25\%. Hasil penelitian menunjukkan bahwa paduan $\mathrm{Zr}-0,6 \mathrm{Nb}-0,5 \mathrm{Fe}-0,5 \mathrm{Cr}$ memiliki struktur Widmanstätten dengan evolusi mikrostruktur menjadi kolumnar terdeformasi dan batang pipih terdeformasi seiring dengan semakin besarnya reduksi ketebalan. Selain itu, semakin lama waktu penahanan pada temperatur $800^{\circ} \mathrm{C}$ maka ukuran butir relatif lebih besar dan terjadi pembentukan fasa $\alpha$-Zr dan $\mathrm{Zr}_{3} \mathrm{Fe}$. Kekerasan paduan $\mathrm{Zr}-0,6 \mathrm{Nb}-0,5 \mathrm{Fe}-0,5 \mathrm{Cr}$ mempunyai kecenderungan yang sama yaitu semakin besar reduksi ketebalan maka semakin tinggi kekerasannya. Paduan $\mathrm{Zr}-0,6 \mathrm{Nb}-0,5 \mathrm{Fe}-$ $0,5 \mathrm{Cr}$ mampu menerima deformasi besar berupa pengerolan panas dengan reduksi ketebalan $25 \%$ dan terbentuknya fasa $\alpha-\mathrm{Zr}$ dan $\mathrm{Zr}_{3} \mathrm{Fe}$ dapat meningkatkan kekerasan dan kekuatan paduan $\mathrm{Zr}-0,6 \mathrm{Nb}-0,5 \mathrm{Fe}-0,5 \mathrm{Cr}$.
\end{abstract}

Kata kunci: Paduan, pengerolan panas, reduksi ketebalan, mikrostruktur, kekerasan, fasa. 


\section{ABSTRACT}

HOT ROLLING EFFECT ON THE CHARACTERS OF Zr-0.6Nb-0.5Fe-0.5Cr ALLOY. Characters of $\mathrm{Zr}-0.6 \mathrm{Nb}-0.5 \mathrm{Fe}-0.5 \mathrm{Cr}$ alloy after hot rolling have been studied. The objective of this research was to obtain of hot rolling effect on the characteristics of microstructures, hardness and phases formed in $\mathrm{Zr}-0.6 \mathrm{Nb}-0.5 \mathrm{Fe}-0.5 \mathrm{Cr}$ alloy. The hot rolling process of alloy carried out at temperature of $800{ }^{\circ} \mathrm{C}$ with retention time of 1.5 and 2 hours and a thickness reduction between 5 to $25 \%$. The results of this experiment showed that the $\mathrm{Zr}-0.6 \mathrm{Nb}-0.5 \mathrm{Fe}-0.5 \mathrm{Cr}$ alloy has Widmanstatten structure with microstructure evolving into deformed columnar grains and deformed elongated grains with increasing thickness reduction. Besides, the longer the retention time at temperature of $800{ }^{\circ} \mathrm{C}$ is the larger are the grain structures and formation of $\alpha-\mathrm{Zr}$ and $\mathrm{Zr}_{3} \mathrm{Fe}$ phase. The hardness of $\mathrm{Zr}-0.6 \mathrm{Nb}-0.5 \mathrm{Fe}-0.5 \mathrm{Cr}$ alloy has same trends i.e the larger thickness reduction gives higher hardness. The $\mathrm{Zr}-0.6 \mathrm{Nb}-0.5 \mathrm{Fe}-0.5 \mathrm{Cr}$ alloy can under go hot rolling deformation at a thickness reduction of $25 \%$ and the formation of $\alpha-Z r$ and $Z r_{3} F e$ can increased of hardness and strength of Zr-0.6 Nb-0.5 Fe-0.5 Cr alloy.

Keywords: Alloy, hot rolling, thickness reduction, microstructure, hardness, phase. 


\section{PENDAHULUAN}

Paduan logam berbasis zirkonium digunakan sebagai material struktur bahan bakar untuk reaktor daya karena mempunyai stabilitas terhadap iradiasi dan ketahanan korosi yang baik serta perilaku mekanik yang memenuhi kriteria keberterimaan dalam lingkungan teras reaktor nuklir. Saat ini telah dikembangkan paduan berbasis zirkonium untuk memenuhi tuntutan efisiensi penggunaan bahan bakar di dalam teras reaktor. Salah satu cara untuk meningkatkan efisiensi bahan bakar adalah dengan menaikkan fraksi bakar yang diikuti dengan kenaikan temperatur operasi reaktor nuklir[1]. Kenaikan fraksi bakar dan temperatur operasi reaktor menyebabkan terjadinya penurunan ketahanan korosi dan ketangguhan material kelongsong ${ }^{[2,3]}$. Untuk mengantisipasi kondisi yang tidak diinginkan, maka dibutuhkan material kelongsong yang mempunyai stabilitas iradiasi, sifat-sifat mekanik dan ketahanan korosi yang baik, serta ekonomis secara neutronik selama penggunaan dalam reaktor nuklir. Material baru sebagai calon pengganti zircaloy-4 untuk kelongsong elemen bakar reaktor PWR maju, salah satunya adalah paduan $\mathrm{Zr}-\mathrm{Nb}-\mathrm{Fe}-\mathrm{Cr}$.

Perilaku material kelongsong dan struktur pada umumnya bergantung pada mikrostruktur bahan serta dipengaruhi oleh komposisi kimia dan proses manufaktur. Kinetika korosi dan perilaku mekanik paduan zirkonium dipengaruhi oleh unsur-unsur pemadu dan presipitat yang terbentuk. Perilaku korosi paduan zirkonium sebagian besar dipengaruhi oleh penambahan niobium $(\mathrm{Nb})$ sebagai unsur pemadu. Selain itu, niobium yang ditambahkan ke dalam paduan berbasis zirkonium berfungsi untukmemperhalus ukuran butir sehingga dapat meningkatkan kekuatan mekanik paduan ${ }^{[4,5]}$. Besi $(\mathrm{Fe})$ dan khrom $(\mathrm{Cr})$ yang ditambahkan sebagai unsur pemadu digunakan untuk meningkatkan kekuatan mekanik yang ditandai dengan terbentuknya presipitat $\mathrm{Zr}(\mathrm{Fe}, \mathrm{Cr})_{2}$ yang keras di dalam paduan zirkonium[6]. Penambahan unsur $\mathrm{Nb}$, Fe dan $\mathrm{Cr}$ tidak berpengaruh secara signifikan terhadap ekonomi neutron termal karena tampang lintang serapan neutron termalnya rendah.

Proses fabrikasi dari bahanbaku hingga menjadi kelongsong elemen bakar untuk reaktor daya melibatkan berbagai proses termo mekanik. Ingot paduan zirkonium direduksi ketebalannya dengan proses pengerolan panas menjadi bloom. Selanjutnya bloom direduksi ketebalannya dengan pengerolan panas menjadi billet atau slab. Tabung kelongsong zirkaloy diperoleh dariproses ekstrusi panas terhadap billet atau slab. Selama proses fabrikasi tersebut akan terjadi perubahan sifat fisis, mekanik, dan kimia dari material kelongsong. Untuk itu perlu dilakukan pengendalian secara ketat terhadap proses fabrikasi material agar diperoleh produk dengan sifat-sifat fisis, mekanis ${ }^{[7]}$ dan kimia yang memenuhi kriteria keberterimaan kelongsong elemen bakar reaktor daya. Salah satu caranya adalah pengendalian mikrostruktur material baik selama pembuatan bahan baku hingga fabrikasinya menjadi kelongsong elemen bakar nuklir. Pengerolan panas merupakan salah satu tahapan proses pembentukan bahan baku kelongsong dan struktur bahan bakar nuklir, yang dilakukan dengan cara melewatkan benda kerja panas pada celah diantara dua buah rol kerja yang berputar pada kecepatan tertentu. Proses pengerolan panas digunakan untuk mereduksi ketebalan benda kerja.

Proses pengerolan terhadap paduan $\mathrm{Zr}-\mathrm{Nb}-\mathrm{Fe}-\mathrm{Cr}$ hasil perlakuan panas akan mengubah bentuk dan ukuran mikrostruktur sehingga paduan mampu menerima deformasi antara 5-10\% tanpa mengalami keretakan ${ }^{[7]}$. Zhinan, et al mendapatkan bahwa proses pengerolan dalam rentang temperatur $200{ }^{\circ} \mathrm{C}$ hingga $850{ }^{\circ} \mathrm{C}$ diketahui bahwa laju transformasi dari fasa $\beta$ menjadi fasa $\omega$, selain itu menyebabkan kekerasan 
paduan Zr-(2-3) Nb-0,2(Fe-Cr) atau Zr705 hasil pengerolan panas menjadi lebih rendah bila dibandingkan dengan paduan hasil pengerolan dingin ${ }^{[8]}$. Lim, et al menyatakan bahwa paduan $\mathrm{Zr}$ dengan $\mathrm{Nb}$ tinggi yang dikenai proses anil pada temperatur antara $600{ }^{\circ} \mathrm{C}$ dan $700{ }^{\circ} \mathrm{C}$ memberikan struktur rekristalisasi seragam dengan nilai kekerasan rendah. Lim juga mendapatkan fakta bahwa mikrostruktur hasil rekristalisasi mempunyai ukuran butir lebih kecil seiring dengan bertambahnya kandungan $\mathrm{Nb}$ dalam paduan $\mathrm{Zr}-\mathrm{Nb}^{[0]}$. Kim et al Kim, et al mendapatkan bahwa kekuatan tarik paduan $\mathrm{Zr}-1 \mathrm{Nb}$ produk ekstrusi panas pada temperatur $400{ }^{\circ} \mathrm{C}$ menurun seiring dengan bertambahnya waktu penahanan pada temperatur tersebut, terutama akibat pertumbuhan butir dan berkurangnya jumlah presipitat $\beta-\mathrm{Nb}^{[10]}$. Wang et al. mendapatkan hasil bahwa paduan $\mathrm{Zr}-0,1 \mathrm{Fe}-0,6 \mathrm{Cr}$ mempunyai ketahanan korosi tinggi dalam lingkungan uap pada $500{ }^{\circ} \mathrm{C}$ karena adanya presipitat $\mathrm{Zr}(\mathrm{Fe}, \mathrm{Cr})_{2}$ dalam matriks relatif banyak dibandingkan paduan $\mathrm{Zr}-\mathrm{Fe}-\mathrm{Cr}$ dengan rentang $\mathrm{Fe}(0,2-1 \%)$ dan $\mathrm{Cr}(0,1-0,6 \%)^{[11]}$. Oh et al mendapatkan bahwa presipitat $\beta-\mathrm{Nb}$ mempunyai kelarutan tinggi terhadap hidrogen sehingga menghambat terjadinya pengendapan hidrida pada antar butir paduan $\mathrm{Zr}-\mathrm{Nb}$. Dengan demikian, apabila kandungan $\mathrm{Nb}$ bertambah tinggi maka dapat meningkatkan ketahanan paduan $\mathrm{Zr}-\mathrm{Nb}$ terhadap penggetasan hidrida[12] .

Berdasarkan hasil penelitian para peneliti tersebut di atas, diketahui bahwa kandungan $\mathrm{Nb}$ menentukan ukuran butir dan penggetasan hidrida, sedangkan waktu penahanan pada perlakuan panas menentukan ukuran butir, kekuatan tarik dan ketahanan korosi paduan $\mathrm{Zr}-\mathrm{Nb}$. Selain itu, dengan adanya presipitat $\mathrm{Zr}(\mathrm{Fe}, \mathrm{Cr})_{2}$ dapat meningkatkan ketahanan korosi pada paduan $\mathrm{Zr}-\mathrm{Fe}-\mathrm{Cr}$ dalam lingkungan atau media uap. Sehubungan hal tersebut, pada penelitian ini dilakukan pengerolan panas terhadap paduan $\mathrm{Zr}-0,6 \mathrm{Nb}-0,5 \mathrm{Fe}-0,5 \mathrm{Cr}$ pada temperatur $800{ }^{\circ} \mathrm{C}$ dengan reduksi ketebalan 5-25\%. Adapun tujuan penelitian ini adalah untuk mendapatkan parameter pengaruh pengerolan panas terhadap karakter mikrostruktur, kekerasan dan fasafasa yang ada dalam ingot paduan $\mathrm{Zr}-0,6 \mathrm{Nb}-0,5 \mathrm{Fe}-0,5 \mathrm{Cr}$ sebagai fungsi reduksi ketebalan. Sementara itu, hipotesa penelitian adalah reduksi ketebalan pada proses pengerolan panas terhadap paduan $\mathrm{Zr}-0,6 \mathrm{Nb}-0,5 \mathrm{Fe}-0,5 \mathrm{Cr}$ diduga dapat mengubah bentuk butir Widmanstaten menjadi berbentuk pipin terdeformasi sehingga diperoleh kekuatan dan kekerasan paduan lebih tinggi tanpa mengalami keretakan.

\section{METODOLOGI}

Bahan yang digunakan dalam kegiatan penelitian ini adalah ingot paduan $\mathrm{Zr}-0,6 \mathrm{Nb}-0,5 \mathrm{Fe}-0,5 \mathrm{Cr}$. Bahan lain yang digunakan untuk preparasi metalografi sampel paduan adalah resin acryfic dan pengeras untuk bingkai sampel, kertas ampelas dan pasta alumina untuk meratakan dan menghaluskan permukaan, sedangkan asam nitrat, asam khlorida, asam fluorida, gliserindan alkohol sebagai bahan larutan etsa.

Peralatan yang digunakan dalam penelitian adalah mesin rol dan tungku pemanas untuk pengerolan panas paduan $\mathrm{Zr}-0,6 \mathrm{Nb}-0,5 \mathrm{Fe}-0,5 \mathrm{Cr}$. Jangka sorong untuk mengukur ketebalan spesimen hasil pengerolan. Mesin potong, mesin gerinda dan poles untuk preparasi metalografi spesimen. Mikroskop optik untuk mengamati mikrostruktur, microhardness Vickers tester untuk menentukan kekerasan mikro (Vickers) dan $X$-ray Difractometer untuk menentukan struktur kristal dan fasa-fasa yang terbentuk dalam ingot paduan $\mathrm{Zr}-0,6 \mathrm{Nb}-0,5 \mathrm{Fe}-0,5 \mathrm{Cr}$.

Cara kerja penelitian yang dilakukan melalui beberapa tahapan yaitu, membuat sampel dengan cara memotong ingot paduan $\mathrm{Zr}-0,6 \mathrm{Nb}-0,5 \mathrm{Fe}-0,5 \mathrm{Cr}$ ke arah vertikal dengan menggunakan mesin potong 
(diamond cutting). Sampel hasil pemotongan kemudian digerinda menggunakan kertas ampelas dengan grit 600. Untuk mengeliminasi permukaan bekas potong, sampel direndam dalam alkohol, dikeringkan dan diukur ketebalannya. Selanjutnya, sampel paduan $\mathrm{Zr}-0,6 \mathrm{Nb}-0,5 \mathrm{Fe}-0,5 \mathrm{Cr}$ dirol pada temperatur $800{ }^{\circ} \mathrm{C}$ dengan waktu penahanan 1,5 dan 2 jam. Pengerolan panas sampel dilakukan dengan reduksi ketebalan 5 sampai $25 \%$. Analisis metalografi dilakukan terhadap sampel ingot leburan danhasil pengerolan panas melalui beberapa tahapanantara lain: pemotongan, pembingkaian, penggerindaan, pemolesan dan pengetsaan sampel. Proses penggerindaan sampel dilakukan menggunakan mesin gerinda dengan kertas ampelas grit 320 sampai dengan grit 1200, pemolesan sampel menggunakan mesin poles dengan pasta alumina grit $0,5 \mu \mathrm{m}$. Sampel hasil pemolesan kemudian dietsa dengan metoda usap menggunakan larutan etsa yang

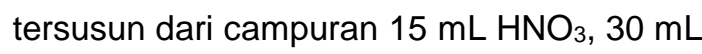
$\mathrm{HF}, 30 \mathrm{~mL} \mathrm{HCl}$, dan $25 \mathrm{~mL}$ aquades. Sampel paduan $\mathrm{Zr}-0,6 \mathrm{Nb}-0,5 \mathrm{Fe}-0,5 \mathrm{Cr}$ kemudian diamati mikrostruktur yang terjadi dengan menggunakan mikroskop optik. Sementara itu, pada proses pengujian kekerasan mikro (Vickers) sampel paduan $\mathrm{Zr}-0,6 \mathrm{Nb}-0,5 \mathrm{Fe}-$ $0,5 \mathrm{Cr}$ hasil pengerolan panas dilakukan dengan menggunakan microhardness Vickers tester, sedangkan pengamatan struktur kristal dan fasa-fasa yang terbentuk di dalam ingot paduan $\quad \mathrm{Zr}-0,6 \mathrm{Nb}-0,5 \mathrm{Fe}-$ $0,5 \mathrm{Cr}$ dilakukan dengan menggunakan peralatan $X$-ray Difractometer ( XRD).

\section{HASIL DAN PEMBAHASAN}

\section{a. Mikrostrukur}

Gambar 1 memperlihatkan mikrostruktur ingot paduan $\mathrm{Zr}-0,6 \mathrm{Nb}-0,5 \mathrm{Fe}-0,5 \mathrm{Cr}$ berupa struktur Widmanstätten di dalam suatu butir dengan ukuran relatif kecil. Adanya struktur Widmanstätten ini ditambah dengan efek segregasi dan stacking fault yang terjadi selama proses presipitasi paduan, maka akan mening-katkan konsentrasi dislokasi dan tegangan sisa dalam paduan $\mathrm{Zr}-0,6 \mathrm{Nb}-0,5 \mathrm{Fe}-0,5 \mathrm{Cr}{ }^{[13]}$. Fenomena ini berdampak pada perilaku ingot paduan yaitu keras dan getas. Hal ini terlihat dari besar kekerasan paduan $\mathrm{Zr}$ $0,6 \mathrm{Nb}-0,5 \mathrm{Fe}-0,5 \mathrm{Cr}$ yaitu sebesar $244 \mathrm{VHN}$.

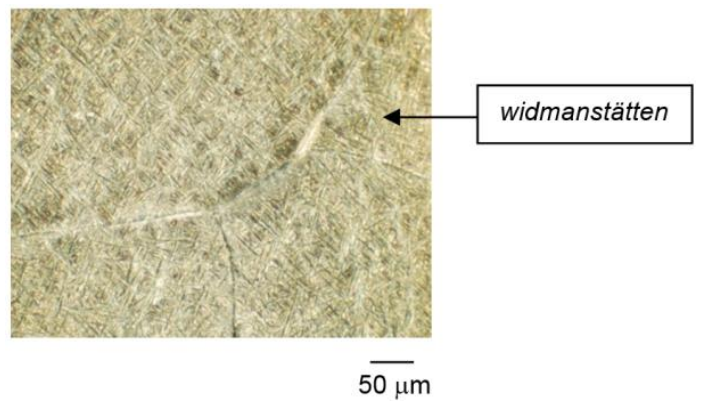

Gambar 1. Mikrograf ingot paduan $\mathrm{Zr}-0,6 \mathrm{Nb}-0,5 \mathrm{Fe}-0,5 \mathrm{Cr}$

Ingot paduan yang bersifat keras dan getas tersebut tidak menguntungkan dalam proses pengerjaan material. Oleh karena itu ingot paduan dirol panas pada temperatur tinggi agar bersifat lunak sehingga deformasi yang diterima menjadi besar tanpa mengalami keretakan. Dalam penelitian ini, proses pengerolan panas $\mathrm{Zr}-0,6 \mathrm{Nb}-0,5 \mathrm{Fe}-0,5 \mathrm{Cr}$ dilakukan pada temperatur $800{ }^{\circ} \mathrm{C}$ dengan waktu penahanan 1,5 dan 2 jam serta reduksi ketebalan $5 \%$ sampai dengan $25 \%$.

Gambar 2 memperlihatkan mikrostruktur paduan $\mathrm{Zr}-0,6 \mathrm{Nb}-0,5 \mathrm{Fe}-0,5 \mathrm{Cr}$ hasil pengerolan panas $\left(800^{\circ} \mathrm{C} ; 1,5\right.$ jam) dengan reduksi ketebalan 5-25\%. Gambar 2 terlihat adanya perubahan struktur butir ingot dari Widmanstätten (Gambar 1) menjadi butir campuran kolumnar dan acicular (Gambar 2a). Proses pemanasan (800 ${ }^{\circ} \mathrm{C}$; 1,5 jam) terhadap paduan $\mathrm{Zr}-0,6 \mathrm{Nb}-0,5 \mathrm{Fe}-0,5 \mathrm{Cr}$ di atas temperatur rekristalisasi yang menyebabkan terjadinya pertumbuhan butir sehingga terjadi perubahan struktur dari Widmanstätten menjadi butir kolumnar dan butir acicular ${ }^{7,9]}$. Kondisi ini menyebabkan terjadinya penurunan tegangan sisa antar butir sehingga paduan $\mathrm{Zr}-0,6 \mathrm{Nb}-0,5 \mathrm{Fe}-0,5 \mathrm{Cr}$ hasil perlakuan panas $\left(800{ }^{\circ} \mathrm{C}\right.$; 1,5 jam $)$ mempunyai kekerasan $239 \mathrm{VHN}$ dan nilai ini 
lebih rendah dibandingkan nilai kekerasan ingot, yaitu sebesar $244 \mathrm{VHN}$.

Pada proses pengerolan panas dengan reduksi ketebalan 5-25\%, paduan mendapat tegangan tekan yang besar dari dua buah rol kerja. Apabila tegangan tekan tersebut mampu ditahan oleh gaya ikat antar atom paduan $\mathrm{Zr}-0,6 \mathrm{Nb}-0,5 \mathrm{Fe}-0,5 \mathrm{Cr}$ hasil pengerolan panas $\left(800{ }^{\circ} \mathrm{C} ; 1,5 \mathrm{jam}\right)$ maka

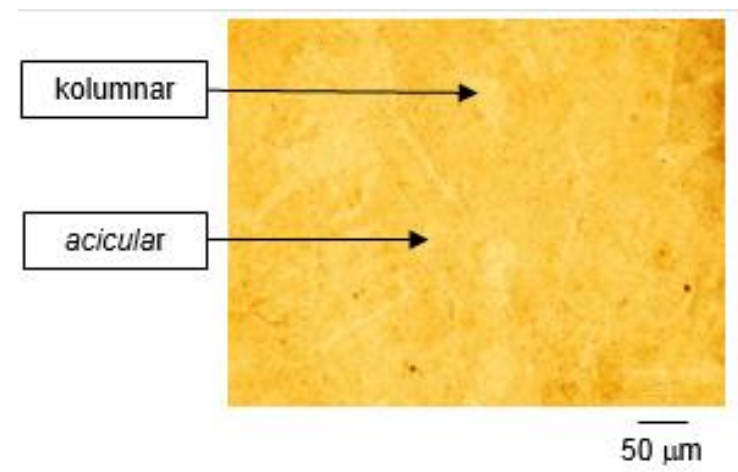

(a)

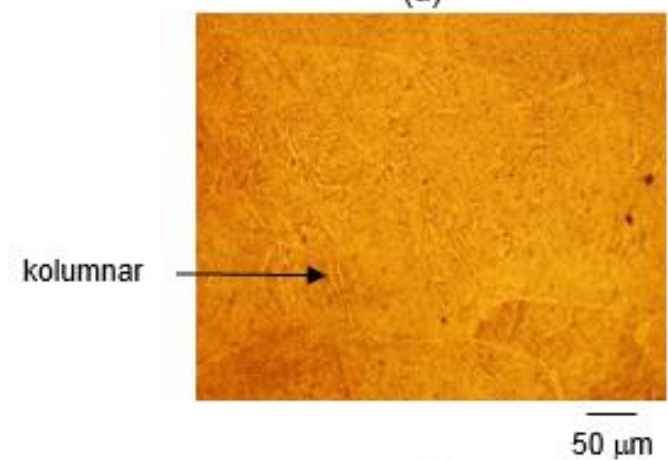

(c)

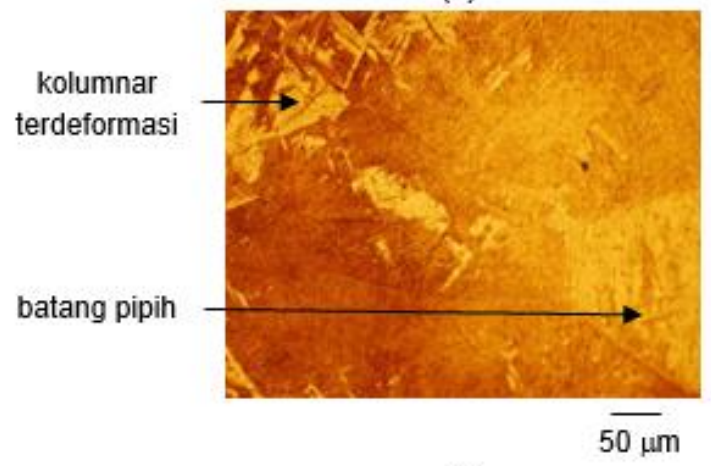

(e) hanya terjadi perubahan bentuk butir dan sampel tidak mengalami keretakan. Semakin besar reduksi ketebalan yang diterapkan maka semakin besar tegangan tekan yang diterima oleh ingot paduan $\mathrm{Zr}$ $0,6 \mathrm{Nb}-0,5 \mathrm{Fe}-0,5 \mathrm{Cr}$. Deformasi ini akan memberikan dampak pada perubahan struktur mikro butir yang semakin pipih, seperti yangditunjukkanoleh Gambar 2.b.

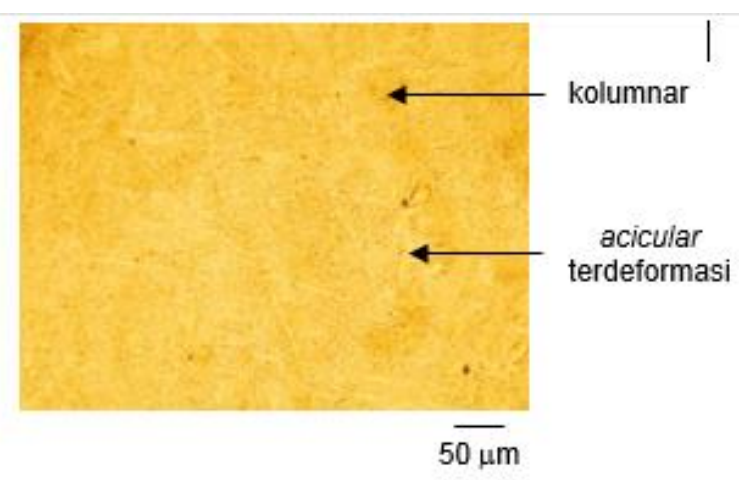

(b)

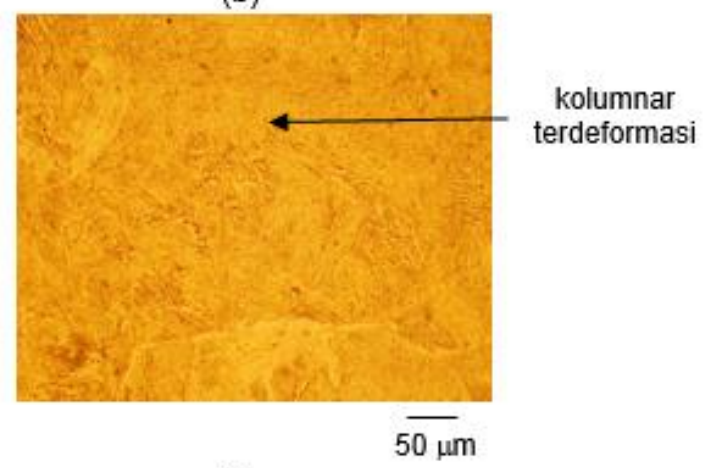

(d)

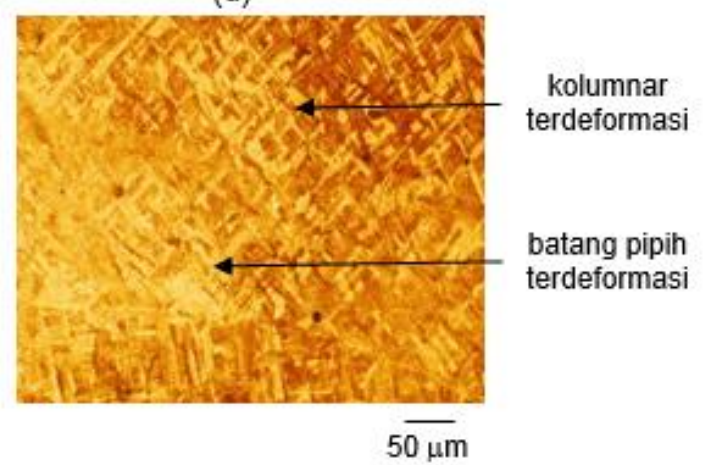

(f)

Gambar 2. Mikrograf paduan $\mathrm{Zr}-0,6 \mathrm{Nb}-0,5 \mathrm{Fe}-0,5 \mathrm{Crhasilpengerolan} \mathrm{panas}\left(800{ }^{\circ} \mathrm{C} ; 1,5 \mathrm{jam}\right)$.

(a) pemanasan ( $r=0 \%$ );(b) $r=5 \%$; (c) $r=10 \%$; (d) $r=15 \%$; (e) $r=20 \%$; (f) $r=25 \%$.

Gambar 2.b menunjukkan campuran butir kolumnar dan acicular terdeformasi pada reduksi $5 \%$, butir kolumnar untuk reduksi $10 \%$ seperti pada Gambar 2c, butir kolumnar terdeformasi padareduksi $15 \%$ seperti pada Gambar 2d, campuran butir kolumnar terdeformasi dan batang pipih pada reduksi $20 \%$ seperti pada Gambar 2e, serta kolumnar terdeformasi dan batang pipih terdeformasi pada reduksi ketebalan $25 \%$ seperti pada Gambar 2f. Perubahan 
bentuk dan ukuran butir tersebut memberikan dampak pada semakin besarnya tegangan sisa antar butir dalam struktur paduan sehingga kekerasan paduan bertambah tinggi. Namun, dari hasil pengamatan secara visual dan mikrostruktur tidak ditemui adanya keretakan pada paduan $\mathrm{Zr}-0,6 \mathrm{Nb}-0,5 \mathrm{Fe}-0,5 \mathrm{Cr}$ dari hasil pengerolan panas $\left(800^{\circ} \mathrm{C} ; 1,5 \mathrm{jam}\right)$ dengan reduksi ketebalan 5 $25 \%$, dengan demikian dapat diketahui bahwa ingot paduan $\mathrm{Zr}-0,6 \mathrm{Nb}-0,5 \mathrm{Fe}-0,5 \mathrm{Cr}$ telah memenuhi syarat untuk menerima perlakuan mekanik berupa pengerolan panas dengan reduksi ketebalan 5-25\% tanpa mengalami keretakan.

Gambar 3 memperlihatkan mikrograf paduan ingot $\mathrm{Zr}-0,6 \mathrm{Nb}-0,5 \mathrm{Fe}-0,5 \mathrm{Cr}$ hasil pengerolan panas $\left(800{ }^{\circ} \mathrm{C}, 2\right.$ jam) dengan reduksi ketebalan $5-25 \%$. Paduan tersebut mempunyai mikrostruktur berupa campuran butir kolumnar dan acicular lebih besar dibandingkan pada perlakuan panas $\left(800^{\circ} \mathrm{C} ; 1,5 \mathrm{jam}\right)$ seperti terlihat pada Gambar 3a. Hal ini terjadi karena proses pemanasan dilakukan pada temperatur di atas temperatur rekristalisasi, sehingga terjadi pertumbuhan butir. Semakin lama waktu penahanan pada temperatur $800{ }^{\circ} \mathrm{C}$ maka semakin besar ukuran butir yang terjadi.

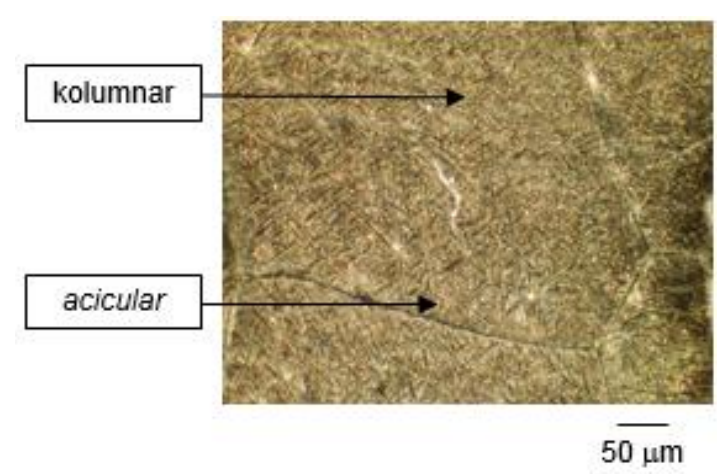

(a)

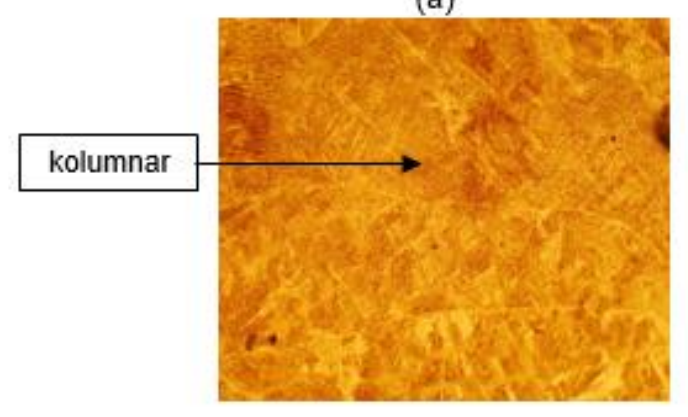

$\overline{50 \mu \mathrm{m}}$

(c)

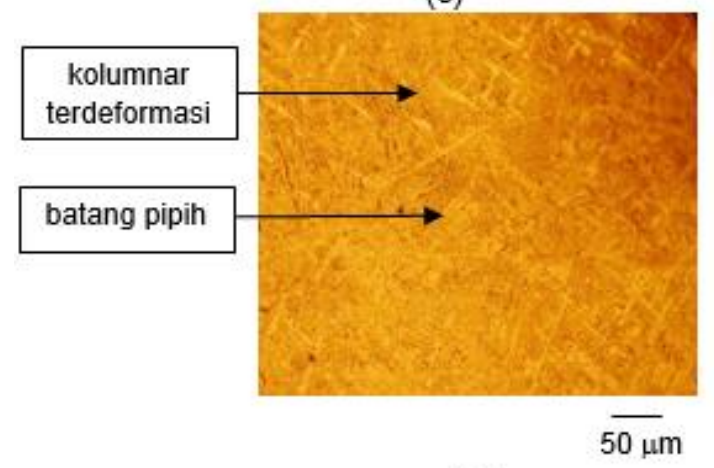

(e)

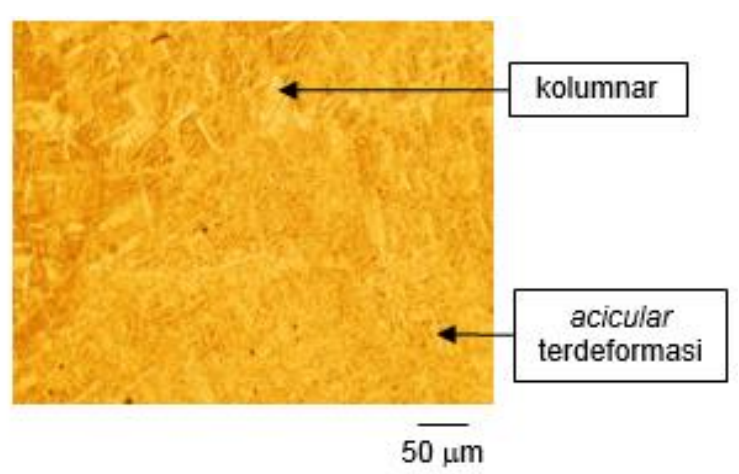

(b)

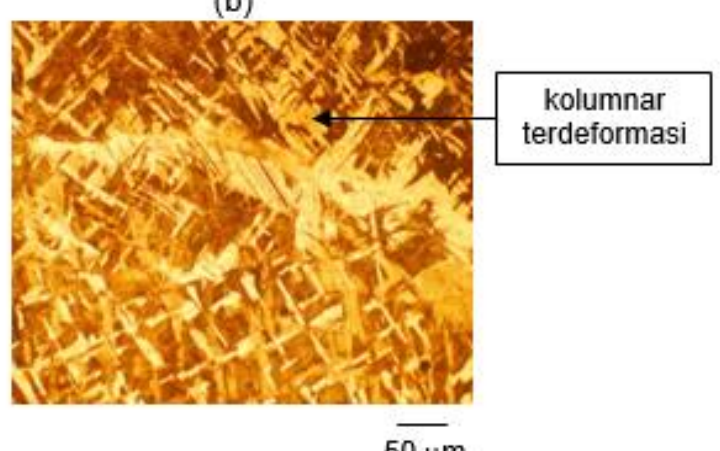

(d)

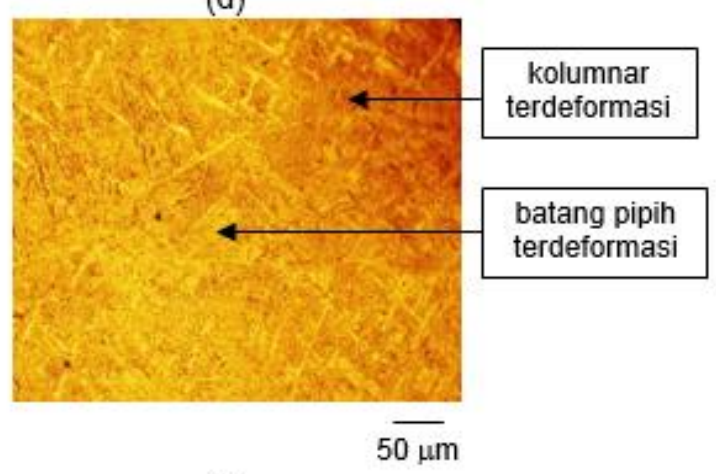

(f)

Gambar3. Mikrograf paduan $\mathrm{Zr}-0,6 \mathrm{Nb}-0,5 \mathrm{Fe}-0,5 \mathrm{Cr}$ hasil pengerolan panas $\left(800{ }^{\circ} \mathrm{C}\right.$; 2jam)

(a) pemanasan ( $r=0 \%$;)(b) $r=5 \%$; (c) $r=10 \%$; (d) $r=15 \%$;(e) $r=20 \%$;f) $r=25 \%$. 
Kondisi ini berdampak pada sifat kekerasan paduan $\mathrm{Zr}-0,6 \mathrm{Nb}-0,5 \mathrm{Fe}-0,5 \mathrm{Cr}$ yang lebih lunak yang tercermin dari nilai kekerasan mikronya yaitu sebesar $236 \mathrm{VHN}$.

Pada proses pengerolan panas dengan reduksi ketebalan $5-25 \%$, paduan $\mathrm{Zr}-0,6 \mathrm{Nb}-0,5 \mathrm{Fe}-0,5 \mathrm{Cr}$ mendapat tegangan tekan yang besar dari dua buah rol kerja. Apabila tegangan tekan tersebut mampu ditahan oleh gaya ikat antar atom paduan ingot $\mathrm{Zr}-0,6 \mathrm{Nb}-0,5 \mathrm{Fe}-0,5 \mathrm{Cr}$ hasil pengerolan panas $\left(800{ }^{\circ} \mathrm{C}\right.$; 2 jam) maka hanya terjadi perubahan bentuk dan ukuran butir dan sampel paduan tidak mengalami keretakan. Demikian pula sebaliknya, apabila gaya ikat antar atom tidak mampu menahan tegangan tekan dari proses pengerolan maka paduan ingot $\mathrm{Zr}-0,6 \mathrm{Nb}-0,5 \mathrm{Fe}-0,5 \mathrm{Cr}$ akan mengalami keretakan. Hasil pengamatan mikrostruktur paduan ingot $\mathrm{Zr}-0,6 \mathrm{Nb}-0,5 \mathrm{Fe}-0,5 \mathrm{Cr}$ hasil pengerolan panas $\left(800{ }^{\circ} \mathrm{C}, 2\right.$ jam) terjadi perubahan bentuk butirdari struktur Widmanstätten ke butir kolumnar dan acicular seperti pada Gambar 3a, butir kolumnar dan acicular terdeformasi untuk reduksi $5 \%$ seperti pada Gambar 3b,butir kolumnar untuk reduksi $10 \%$ seperti pada Gambar 3c, butir kolumnar terdeformasi untuk reduksi $15 \%$ seperti pada Gambar 3d, kolumnar terdeformasi dan batang pipih untuk reduksi $20 \%$ seperti pada Gambar 3e serta kolumnar terdeformasi dan batang pipih terdeformasi untuk reduksi ketebalan $25 \%$ seperti pada Gambar 3f. Evolusi struktur butir tersebut terjadi karena adanya persaingan antara pertumbuhan butir dan deformasi sehingga bentuk butir serupa tetapi ukuran butirnya lebih besar dibandingkan dengan paduan ingot $\mathrm{Zr}-0,6 \mathrm{Nb}-0,5 \mathrm{Fe}-0,5 \mathrm{Cr}$ hasil pengerolan panas (800 $\stackrel{\circ}{ } \mathrm{C}, 1.5 \mathrm{jam})$.

Pengerolan panas menyebabkan deformasi paduan $\mathrm{Zr}-0,6 \mathrm{Nb}-0,5 \mathrm{Fe}-0,5 \mathrm{Cr}$ sehingga bentuk butirnya lebih pipih. Semakin besar deformasi yang diterapkan pada paduan maka semakin besar pula tegangan tekan yang harus diterima atomatom dari paduan $\mathrm{Zr}-0,6 \mathrm{Nb}-0,5 \mathrm{Fe}-0,5 \mathrm{Cr}$.
Kondisi tersebut mengakibatkan terjadinya efek pengerasan regangan (strain hardening) pada paduan, sehingga semakin besar deformasi yang diterapkan maka pengerasan regangan semakin tinggi dan paduan semakin keras ${ }^{[8,14]}$. Hal ini ditunjukkan dengan adanya butir berupa batang pipih terdeformasi dalam mikrostruktur paduan $\mathrm{Zr}-0,6 \mathrm{Nb}-0,5 \mathrm{Fe}-0,5 \mathrm{Cr}$ hasil pengero lan panas (800 ${ }^{\circ} \mathrm{C} ; 1,5$ jam) dengan reduksi ketebalan $15-25 \%$ dan $\left(800^{\circ} \mathrm{C}, 2\right.$ jam $)$ dengan reduksi ketebalan sebesar 10-25\%.

Dari Gambar 2 dan 3 diketahui bahwa untuk reduksi ketebalan $5-25 \%$, mikrostruktur paduan $\mathrm{Zr}-0,6 \mathrm{Nb}-0,5 \mathrm{Fe}-0,5 \mathrm{Cr}$ hasil pengerolan panas $\left(800{ }^{\circ} \mathrm{C} ; 2\right.$ jam $)$ mempunyai butir serupa tetapi ukurannya lebih besar sehingga kekerasannya lebih rendah dibandingkan dengan paduan ingot $\mathrm{Zr}-0,6 \mathrm{Nb}-0,5 \mathrm{Fe}-0,5 \mathrm{Cr}$ hasil pengerolan panas $\left(800{ }^{\circ} \mathrm{C} ; 1,5 \mathrm{jam}\right)$. Selain itu juga diketahui bahwa $\mathrm{Zr}-0,6 \mathrm{Nb}-0,5 \mathrm{Fe}-0,5 \mathrm{Cr}$ hasil pengerolan panaspada (800 ${ }^{\circ} \mathrm{C}$; $1,5 \mathrm{jam}$ ) dan (800 ํ; 2 jam) mampu menerima deformasi dengan reduksi ketebalan $5-25 \%$ tanpa mengalami keretakan.

\section{b. Kekerasan}

Kekerasan merupakan ukuran ketahanan material terhadap deformasi. Hasil pengujian kekerasan mikro paduan ingot $\mathrm{Zr}-0,6 \mathrm{Nb}-0,5 \mathrm{Fe}-0,5 \mathrm{Cr}$ sebelum dan sesudah pengerolan panas sebagai fungsi reduksi ketebalan diperlihatkan pada Gambar 4. Gambar 4 memperlihatkan bahwa kekerasan paduan $\mathrm{Zr}-0,6 \mathrm{Nb}-0,5 \mathrm{Fe}-0,5 \mathrm{Cr}$ hasil pengerolan panas $\left(800{ }^{\circ} \mathrm{C}\right.$; $\left.1,5 \mathrm{jam}\right)$ dan $\left(800{ }^{\circ} \mathrm{C}\right.$; 2 jam) meningkat seiring dengan bertambah tingginya reduksi ketebalan yang diterapkan terhadap paduan $\mathrm{Zr}-0,6 \mathrm{Nb}-0,5 \mathrm{Fe}-0,5 \mathrm{Cr}$. Hal ini disebabkan reduksi ketebalan yang dikanakan pada pengerolan panas paduan $\mathrm{Zr}-0,6 \mathrm{Nb}-0,5 \mathrm{Fe}-$ $0,5 \mathrm{Cr}$ akan menyebabkan terjadinya deformasi terhadap ingot $\mathrm{Zr}-0,6 \mathrm{Nb}-0,5 \mathrm{Fe}-0,5 \mathrm{Cr}$. Semakin bertambah besar reduksi ketebalan maka semakin tinggi tegangan tekan yang diterima oleh paduan sehingga mengubah 
bentuk dan ukuran butir dalam mikrostruktur $\mathrm{Zr}-0,6 \mathrm{Nb}-0,5 \mathrm{Fe}-0,5 \mathrm{Cr}$ menjadi lebih pipih. Perubahan bentuk butir ini menyebabkan tegangan sisa dalam struktur menjadi meningkat yang selanjutnya menaikkan kerapatan dislokasi dan disertai dengan efek pengerasan regangan (strain hardening) ${ }^{[7,14]}$.

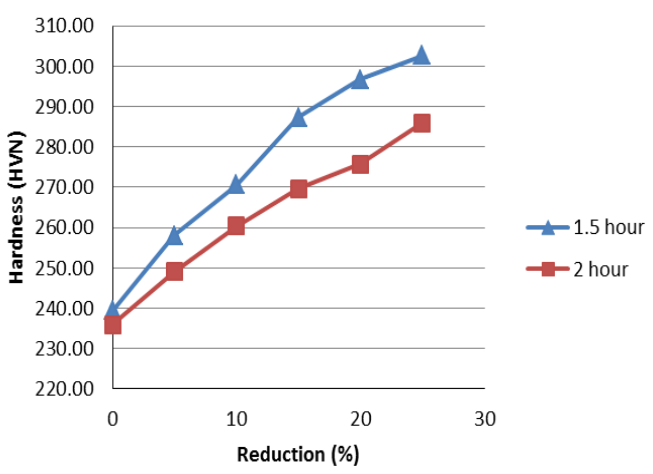

Gambar 4. Hubungan antara nilai kekerasan terhadap reduksi ketebalan paduan $\mathrm{Zr}-0,6 \mathrm{Nb}-0,5 \mathrm{Fe}-0,5 \mathrm{Cr}$ hasil pengerolan panas $\left(800{ }^{\circ} \mathrm{C}\right.$; 1,5 jam) dan $\left(800{ }^{\circ} \mathrm{C} ; 2\right.$ jam).

Selain itu, kekerasan paduan ingot $\mathrm{Zr}-0,6 \mathrm{Nb}-0,5 \mathrm{Fe}-0,5 \mathrm{Cr}$ hasil pengerolan panas $\left(800{ }^{\circ} \mathrm{C} ; 2\right.$ jam) lebih rendah dibandingkan dengan kekerasan paduan $\mathrm{Zr}-0,6 \mathrm{Nb}-0,5 \mathrm{Fe}-0,5 \mathrm{Cr}$ hasil pengerolan panas $\left(800{ }^{\circ} \mathrm{C}\right.$; 1,5 jam) dalam rentang reduksi ketebalan antara $5-25 \%$. Hal ini disebabkan karena semakin lama waktu penahanan pada temperatur yang sama akan berdampak pada penataan kembali atom-atom dan butir-butir kecil bergabung satu sama lain sehingga terjadi pertumbuhan butir yangditandai dengan terbentuknya butir-butir baru yang lebiih besar. Oleh karena $\mathrm{Zr}-0,6 \mathrm{Nb}-0,5 \mathrm{Fe}-0,5 \mathrm{Cr}$ hasil pengerolan panas $\left(800{ }^{\circ} \mathrm{C}\right.$; 2 jam) dari awal butirnya lebih besar bila dibandingkan dengan paduan $\mathrm{Zr}-0,6 \mathrm{Nb}-0,5 \mathrm{Fe}-0,5 \mathrm{Cr}$ hasil pengerolan panas $\left(800{ }^{\circ} \mathrm{C} ; 1,5\right.$ jam $)$ sehingga apabila mendapat perlakuan pengerolan panas yang sama maka butir yang terbentuk cenderung lebih besar untuk reduksi ketebalan 5-25\%. Semakin besar ukuran butirnya maka kekerasan paduan $\mathrm{Zr}-0,6 \mathrm{Nb}-0,5 \mathrm{Fe}-0,5 \mathrm{Cr}$ semakin rendah atau bertambah lunak. Hal ini sesuai dengan persamaan Hall-Petch ${ }^{[7,14]}$.

\section{c. Kristalografi}

Gambar 5, 6 dan 7 memperlihatkan spektrum hasil pengujian XRD terhadap paduan $\mathrm{Zr}-0,6 \mathrm{Nb}-0,5 \mathrm{Fe}-0,5 \mathrm{Cr}$ sebelum dan sesudah pengerolan panas dengan reduksi ketebalan 25 \%. Puncak spektrum kemudian diidentifikasi fasa dan struktur kristal yang terbentuk menggunakan data basis PDF2. Analisis terhadap puncak spektrum tersebut dilakukan dalam rentang $2 \theta$ antara 20 sampai $38^{\circ}$ seperti pada Gambar 5, 38 sampai $50^{\circ}$ pada Gambar 6) dan 50 sampai $60^{\circ}$ pada Gambar $7^{[15]}$.

Pada Gambar 5 terlihat adanya puncak-puncak spektrum dalam sampel paduan $\mathrm{Zr}-0,6 \mathrm{Nb}-0,5 \mathrm{Fe}-0,5 \mathrm{Cr}$ sebelum dan sesudah pengerolan panas.

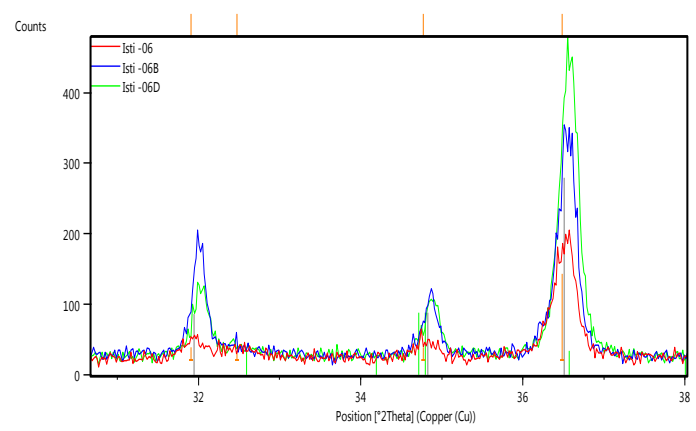

Gambar 5. Identifikasi puncak paduan ingot $\mathrm{Zr}-0,6 \mathrm{Nb}-0,5 \mathrm{Fe}-0,5 \mathrm{Cr}$ sebelum dan sesudah pengerolan panas dengan reduksi ketebalan $25 \%$ dalam rentang $2 \theta$ antara $20-38^{\circ}$.

Spektrum tersebut terdiri dari tiga puncak spektrum berwarna merah untuk paduan sebelum dirol panas, tiga puncak spektrum berwarna biru untuk paduan ingot hasil pengerolan panas $\left(800{ }^{\circ} \mathrm{C}\right.$; 1,5 jam) dan tiga puncak spektrum berwarna hijau untuk paduan ingot hasil pengerolan panas $\left(800^{\circ} \mathrm{C} ; 2\right.$ jam) pada $2 \theta$ masing-masing adalah $32,09^{\circ} ; 34,9^{\circ}$ dan $36,47^{\circ}$. Puncakpuncak spektrum tersebut selanjutnya dilakukan identifikasi terhadap fasa yang terbentuk. Berdasarkan data basis PDF2, untuk paduan sebelum dirol panas fasa yang terbentuk adalah fasa $\mathrm{Zr}_{3} \mathrm{Fe}$ sesuai 
nomor referensi 00-039-0816 dan $\alpha-Z r$ sesuai nomor referensi 01-089-3045. Sementara itu, paduan hasil pengerolan panas $\left(800{ }^{\circ} \mathrm{C}\right.$; 1,5 jam $)$ mempunyai fasa $\mathrm{Zr}_{3} \mathrm{Fe}$ sesuai dengan nomor referensi 00-039-0816 dan fasa $\alpha-\mathrm{Zr}$ sesuai nomor referensi 01-089-4791, sedangkan fasa pada paduan hasil pengerolan panas (800 ${ }^{\circ} \mathrm{C}$; 2 jam) adalah $\mathrm{Zr}_{3} \mathrm{Fe}$ sesuai nomor referensi 00-039-0816 dan $\alpha-Z r$ sesuai nomor referensi 01-089-3045.

Dalam rentang $2 \theta$ antara $38-50^{\circ}$ terdapat satu puncak spektrum pada sampel paduan $\mathrm{Zr}-0,6 \mathrm{Nb}-0,5 \mathrm{Fe}-0,5 \mathrm{Cr}$ sebelum dan sesudah pengerolan panas seperti pada Gambar 6. Berdasarkan data basis PDF2 referensi 01-089-4791 diketahui fasa yang terbentuk adalah $\mathrm{Zr}+\mathrm{Zr}_{3} \mathrm{Fe}$ pada $2 \theta$ yaitu $46,2^{\circ}$ baik untuk paduan sebelum maupun hasil pengerolan panas. Dalam hal ini, fasa $\mathrm{Zr}+\mathrm{Zr}_{3} \mathrm{Fe}$ hasil pengerolan panas secara kuantitas lebih banyak dibandingkan fasa $\mathrm{Zr}+\mathrm{Zr}_{3} \mathrm{Fe}$ pra pengerolan panas. Dengan demikian, semakin lama pemanasan diterapkan pada paduan maka kuantitas fasa $\mathrm{Zr}+\mathrm{Zr}{ }_{3} \mathrm{Fe}$ semakin besar.

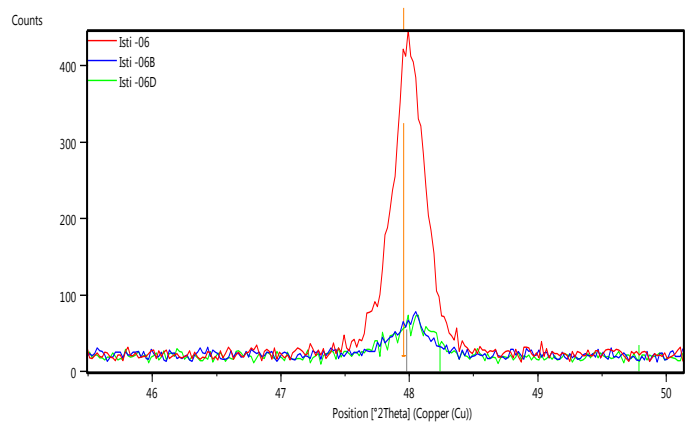

Gambar 6.Identifikasi puncak paduan ingot $\mathrm{Zr}-0,6 \mathrm{Nb}-0,5 \mathrm{Fe}-0,5 \mathrm{Cr}$ hasil pengerolan panas $\left(800{ }^{\circ} \mathrm{C} ; 2\right.$ jam) dengan reduksi ketebalan $25 \%$ dalam rentang $2 \theta$ antara $38-50^{\circ}$

Gambar 7 menunjukkan bahwa dalam rentang $2 \theta$ antara $50-60^{\circ}$ terdapat satu puncak spektrum pada sampel paduan $\mathrm{Zr}-0,6 \mathrm{Nb}-0,5 \mathrm{Fe}-0,5 \mathrm{Cr}$ sebelum dan sesudah pengerolan panas. Puncak spektrum paduan tersebut terdapat pada $2 \theta$ yaitu $56,921^{\circ}$. Setelah diidentifikasi dengan data basis PDF2 referensi 00-089-3045 diketahui bahwa fasa yang ada adalah $\alpha-Z r$. Kuantitasi fasa $\alpha-Z r$ dipengaruhi oleh proses pengerolan panas yaitu semakin lama waktu pemanasan maka semakin besar fasa $\alpha-Z r$ dalam paduan $\mathrm{Zr}-0,6 \mathrm{Nb}-0,5 \mathrm{Fe}-0,5 \mathrm{Cr}$.

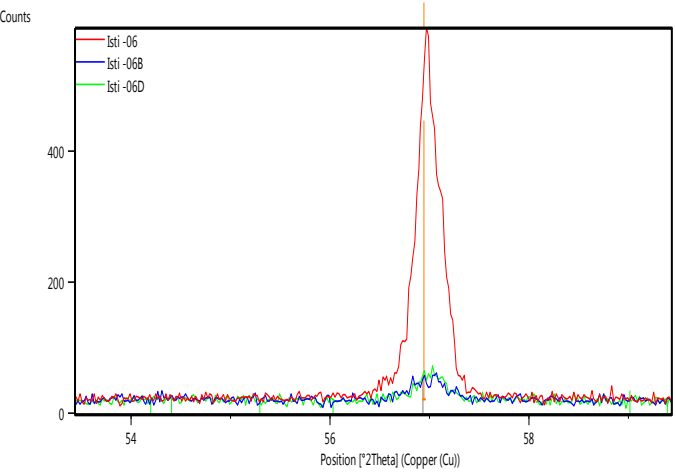

Gambar 7. Identifikasi puncak paduan ingot $\mathrm{Zr}-0,6 \mathrm{Nb}-0,5 \mathrm{Fe}-0,5 \mathrm{Cr}$ hasil pengerolan panas $\left(800{ }^{\circ} \mathrm{C}\right.$; 2 jam) dengan reduksi ketebalan $25 \%$ dalam rentang $2 \theta$ antara $50-60^{\circ}$

Berdasarkan Gambar 5, 6 dan 7 diketahui bahwa fasa yang terbentuk di dalam paduan $\mathrm{Zr}-0,6 \mathrm{Nb}-0,5 \mathrm{Fe}-0,5 \mathrm{Cr}$ hasil pengerolan panas dengan reduksi ketebalan sebesar $25 \%$ adalah fasa $\alpha-Z r$ yang banyak mengandung $\mathrm{Nb}$ dan fasa $\mathrm{Zr}_{3} \mathrm{Fe}$. Fasa $\alpha-\mathrm{Zr}$ tersebut mempunyai struktur kristal heksagonal tumpukan padat (HCP) dengan parameter kisi: $a=3,2321 \AA$, $b=3,2321 \AA$ dan $c=5,1477 \AA$. Pada temperatur pengerolan dan reduksi ketebalan yang tinggi, kemungkinan disebabkan oleh atom-atom $\mathrm{Nb}$ larut padat ke dalam butir dan batas butir $\mathrm{Zr}$ semakin tinggi[16]. Hal ini menyebabkan terjadinya kenaikan kekerasan paduan ingot $\mathrm{Zr}-0,6 \mathrm{Nb}-0,5 \mathrm{Fe}-0,5 \mathrm{Cr}$.

Proses pengerolan panas paduan ingot $\mathrm{Zr}-0,6 \mathrm{Nb}-0,5 \mathrm{Fe}-0,5 \mathrm{Cr}$ menyebabkan atom-atom $\mathrm{Fe}$ dan $\mathrm{Cr}$ yang mempunyai kelarutan rendah dalam fasa $\alpha-Z r$ yang berpotensi membentuk presipitat $\mathrm{Zr}_{3} \mathrm{Fe}^{[2]}$. Presipitat $\mathrm{Zr}_{3} \mathrm{Fe}$ mempunyai struktur kristal ortorombik dengan parameter kisi: $a=3,3200 \AA, b=10,9800 \AA, c=8,8000 \AA$. Pada proses pengerolan panas paduan dengan $\mathrm{Fe} / \mathrm{Cr}<4$ dapat terjadi pembentukan fasa $\mathrm{Zr}_{3} \mathrm{Fe}$, tetapi tidak menyebabkan terbentukfasa $\mathrm{Zr}(\mathrm{Fe}, \mathrm{Cr}) 2^{[16]}$. Terbentuknya 
fasa $\mathrm{Zr}_{3} \mathrm{Fe}$ yang disebabkan pengerolan panas, dapat meningkatkan kekerasan dan kekuatan paduan $\mathrm{Zr}-0,6 \mathrm{Nb}-0,5 \mathrm{Fe}-0,5 \mathrm{Cr}$.

\section{SIMPULAN}

Pengerolan panas terhadap paduan ingot $\mathrm{Zr}-0,6 \mathrm{Nb}-0,5 \mathrm{Fe}-0,5 \mathrm{Cr}$ menyebabkan terjadinya perubahan mikrostruktur dari Widmanstatten menjadi acicular. Perubahan mikrostruktur dari acicular menjadi acicular terdeformasi, kolumnar, kolumnar terdeformasi, batang pipih dan batang pipih terdeformasi seiring dengan besarnya reduksi ketebalan pada proses pengerolan panas yang diterapkan pada paduan. Pada pengerolan panas, kekerasan paduan ingot $\mathrm{Zr}-0,6 \mathrm{Nb}-0,5 \mathrm{Fe}-0,5 \mathrm{Cr}$ bertambah tinggi seiring dengan besarnya reduksi ketebalan yang diterapkan pada paduan. Kekerasan paduan $\mathrm{Zr}-0,6 \mathrm{Nb}-0,5 \mathrm{Fe}-0,5 \mathrm{Cr}$ meningkat akibat pengerasan regangan yang terjadi selama proses pengerolan panas. Paduan $\mathrm{Zr}-0,6 \mathrm{Nb}-0,5 \mathrm{Fe}-0,5 \mathrm{Cr}$ mampu menerima deformasi yang besar dengan reduksi ketebalan sebesar 5-25\% tanpa mengalami keretakan.

Fasa yang terbentuk dalam paduan ingot $\mathrm{Zr}-0,6 \mathrm{Nb}-0,5 \mathrm{Fe}-0,5 \mathrm{Cr}$ hasil pengerolan panas dengan reduksi ketebalan $25 \%$ adalah $\alpha-Z r$ yang mempunyai struktur kristal $\mathrm{HCP}$ dan presipitat $\mathrm{Zr}_{3} \mathrm{Fe}$ dengan struktur kristal orthorombik. Adanya kedua fasa tersebut dapat meningkatkan kekuatan dan kekerasan paduan $\mathrm{Zr}-0,6 \mathrm{Nb}-0,5 \mathrm{Fe}-0,5 \mathrm{Cr}$.

\section{UCAPAN TERIMA KASIH}

Penulis mengucapkan terima kasih kepada Yatno Dwi Agus Santosa, Isfandi, A.Md, Ir. Bangun Wasito, M.Sc dan Dr. Jan Setiawan, M.Si yang telah membantu dalam pelaksanaan penelitian ini.

\section{DAFTAR PUSTAKA}

[1] Rudling, P., R. Adamson, B. Cox, F. Garzarolli and A. Strasser, (2008), High Burnup Fuel Issues, Nuclear
Engineering and Technology,.40 (1), Hal. 1-8.

[2] Long, F., (2015), Characterization of Deformation Mechanism in Zirconium Alloys: Effect of Temperature and Irradiation, Thesis, Dept. of Mechanical and Material Engineering, Queen's University Kingston, Canada, Hal. 182209.

[3] Barrett K., S. B. Sitton and D. Galicki, (2012), Nuclear Fuel Cladding System Development Trade-off Study, INL/EXT12-27090, Idaho National Laboratory, Hal. 19-20.

[4] Kim, H. G., S. Y. Park, M. H. Lee, Y. H. Jeong, S. D. Kim, (2008), Corrosion and Microstructural Characteristics of $\mathrm{Zr}-\mathrm{Nb}$ Alloys with Different $\mathrm{Nb}$ Contents, J. of Nuclear Materials 373 , Hal.429-432.

[5] Woo, O.T. and M. Griffiths, (2009). The Role of Fe on The Solubility of $\mathrm{Nb}$ in $\alpha$ $Z r$, J. of Nuclear Materials, 384, Hal. 7780.

[6] Motta, A.T., A. Yilmazbayhan, M.J. Gomes da Silva, R.J. Comstock, G.S. Was, J.T. Busby, E. Gurtner, Q. Peng, Y.H. Jeong and J.Y. Park, (2009). Zirconium Alloys for Supercritical Water Reactor Applications: Challenges and Possibilities, J. of Nuclear Materials, 371, Hal. 61-75.

[7] Sungkono, Masrukan, (2015), Analisis Mikrostruktur dan Kristalografi Paduan $\mathrm{Zr}-0,3 \% \mathrm{Nb}-0,5 \% \mathrm{Fe}-0,5 \% \mathrm{Cr} \quad$ Pasca Perlakuan Panas danPengerolan Dingin, J. Daur Bahan Bakar Nuklir Urania, 21 (2), Hal. 65-75.

[8] Zhinan, Y., L. Fengchao, Y. Zhigang, Z. Fucheng, (2013), Effect of Annealing on Microstructure and Hardness of Hot and Cold Rolled Zr705, J. Rare Metal Materials and Engineering 42 (2), Hal. $254-258$.

[9] Lim, Y.S. H.G. Kim and Y.H. Jeong, (2008), Recrystallization Behavior of Zr$x$ Nb Alloys, Materials Transaction, 49 (7), Hal. 1702-1705. 
[10] Kim, T.K., P.S. Choi, S.K. Yang, C.T. Lee and D.S. Shon, (2008), Correlation Between The Tensile Strength and Corrosion Behavior of Heat Treated $\mathrm{Zr}$ 1.0 Nb Alloy, Nuclear Engineering and Technology, 40 (6), Hal. 505-510.

[11] Wang, J., H. Fan, J. Xiong, H. Liu, Z. Miao, S. Ying and G. Yang, (2011), Effects of $\mathrm{Fe}$ and $\mathrm{Cr}$ on Corrosion Behaviour of $\mathrm{ZrFeCr}$ Alloys in $500{ }^{\circ} \mathrm{C}$ Steam, J. Nuclear Engineering and Design, 241, Hal. 471-475.

[12] Oh, S., C.i Jang, J. H. Kim, Y. H. Jeong, (2010), Effect of $\mathrm{Nb}$ on Hydride Embrittlement of $\mathrm{Zr}-\mathrm{xNb}$ Alloys,J. Material Science and Engineering, Vol. 527, Hal. 1306-1313.

[13] Chouduri, G., S. Chakraborty, D. Srivastava and G. K. Dey, (2013), Phase Field Modeling of Widmanstatten Plate Formation in Zr-2.5Nb Material, Results in Physics 3, Hal. 7-13.
[14] Choi, M. Y., C. Y. Lee, Y. Kim, Y. K. Mok, S. J. Lee, J..M. Suh, (2013), Effects of Final Annealing on the Corrosion Behavior and Hardness of Zr$\mathrm{Nb}$-Fe-P Alloy, Transactions of the Korean Nuclear Society.

[15] Min Ma, M. Li, Y. Tan, H. Yuan and W. Liu,(2014),Microstructure and Texture Evolution in Commercial-Purity $\mathrm{Zr} 702$ During Cold Rolling and Annealing, J. of Minerals, Metalurgy and Materials, 21 (8), Hal. 75-79.

[16] Straumal, B. B., A. S. Gornakova, Y. O. Kucheev, B. Baretzky and A. N. Nekrazov, (2012), Grain Boundary Wetting by a Second Solid Phase in the Zr-Nb Alloys, JMEPEG, 21, Hal. 721724. 